\title{
"Pulling hair out of the head" - the importance of traumatic family events in the development and maintenance of trichotillomania symptoms - case report
}

\author{
„Rwać włosy z głowy” -o znaczeniu traumatycznych wydarzeń rodzinnych w powstawaniu \\ i podtrzymywaniu objawów trichotillomanii- opis przypadku
}

\section{Aleksandra Siek ${ }^{1}$ ABDEF, Agata Makarewicz ${ }^{1}$ ABD, Łukasz Łobejko ${ }^{1}$ ABD, Anna Gralewska ${ }_{\mathrm{BDEF}}$, Joanna Tomaka ${ }_{\mathrm{EF}}$, Justyna Szymańska - Piekarczyk ${ }^{1}{ }_{\mathrm{EF}}$, Jakub Siembida $^{3}$ EF, Hanna Karakuła Juchnowicz ${ }^{2}$ ADEF}

${ }^{1}$ I Department of Psychiatry, Psychotherapy and Early Intervention, Medical University of Lublin

2 Department of Clinical Neuropsychiatry, Medical University of Lublin

${ }^{3}$ Student Research Group at the I Department of Psychiatry, Psychotherapy and Early Intervention, Medical

University of Lublin

\begin{abstract}
Introduction: Trichotillomania is a mental disorder characterized by a repetitive and compulsive hair pulling, classified in ICD-10 to a group of habit and impulse disorders, and in the DSM-5 to the group of obsessive-compulsive disorders.

Aim: The aim of the study is to present on the basis of case study:1). the importance of traumatic family experiences in rele asing as well as maintaining the symptoms of Trichotillomania, 2). comprehensive medical care, the application of which has resulted in a beneficial therapeutic effect.

Results: In the described case of 16-year-old patient, Trichotillomania was triggered by traumatic events related to lack of support and family stabilization resulting from parental disputes and grandfather's death, when she was 11 years old. The subsequent years of her life, in spite of the divorce of her parents and their separate residence, abounded in periods of turbulent quarrels between the parents in which she was involved. Each time this type of incident was associated with the recurrence of behavior associated with Trichotillomania, the course of which was more severe with the occurrence of self-harm and suicidal thoughts.

Conclusions: 1. In the described case, traumatic events and pathological relations of the immediate family members were not only thetriggering factor, but also maintaining the Trichotillomania symptoms. 2. In accordance with the guidelines of Trichotillomania Learning Center-Scientific Advisory Board (2008), the use of a comprehensive treatment including both the patient - individual psychotherapy (especially cognitive-behavioral therapy) and pharmacotherapy, as well as her family (family psychotherapy, family mediation, workshops for parents), brought about po sitive therapeutic effects.
\end{abstract}

Keywords: trichotillo mania, obsessive-compulsive disorder, CBT

\section{Streszczenie}

Wstęp: Trichotillomania jest zaburzeniem psychicznym charakteryzującym się powtarzalnym i kompulsywnym wyrywaniem włosów, zaliczonym w klasyfikacji ICD-10 do grupy zaburzeń nawyków i popędów, zaś w klasyfikacji DSM-5 do grupy zaburzeń obsesyjno-kompulsyjnych. Cel: Celem pracy jest przedstawienie na podstawie opisu przypadku 1. znaczenia traumatycznych przeżyć rodzinnych w wyzwoleniu, jak i podtrzymaniu objawów Trichotillomanii, 2. kompleksowej opieki medycznej, której zastosowanie przyniosło korzystny efekt terapeutyczny. Wyniki: W opisywanym przypadku 16-letniej pacjentki, traumatyczne wydarzenia życiowe związane z poczuciem braku oparcia i stabilizacji rodzinnej wynikające z kłótni rodziców i śmierci dziadka w wieku 11 lat, były czynnikiem wyzwalającym Trichotillomanię. Kolejne lata życia pacjentki, pomimo rozwodu rodziców i ich osobnego zamieszkiwania, obfitowały w okresy burzliwych nieporozu mień pomiędzy rodzicami, w które pacjentka była angażowana. Każdorazowo tego typu incydent wiązał z nawrotem zachowań związanych z Trichotillomanią, których przebieg był coraz cięższy z występowaniem samookaleczeń i myśli samobójczych.

Wnioski: 1. W opisanym przypadku traumatyczne wydarzenia życiowe oraz patologiczne relacje najbliższych członków rodziny stały się czynnikiem wyzwalającym, ale i podtrzymującym objawy Trichotillomanii. 2. Zgodnie z wytycznymi Trichotillomania Learning Center-Scientific Advisory Board (2008) zastosowanie kompleksowego leczenia obejmującego swym zakresem zarówno pacjentkę psychoterapia indywidualna (głównie kognitywno-behawioralna) łącznie z farmakoterapią, jak i jej system rodzinny (psychoterapia rodzinna, mediacja rodzinna, warsztaty dla rodziców) przyniosło pozytywne efekty terapeutyczne.

Słowa kluczowe: trichotillomania, zaburzenia obsesyjno-kompulsyjne, terapia kognitywno - behawioralna

(C) 2017 Medical University of Lublin. This is an open access article distributed under the Creative Commons Attribution-NonComercial-No Derivs licence (http://creativecommons.org/licenses/by-nc-nd/3.0/) 


\section{Introduction}

Trichotillomania (TTM) is a disorder characterized by repetitive and compulsive hair pulling, classified in the ICD-10 as habit and impulse disorders (F63.3) [1], and in the DSM-5 as a group of obsessive-compulsive disorders under the new name: hair pulling disorder [2]. Prevalence of TTM is estimated at $0.6-3.4 \%$ of the population [3], of which almost $90 \%$ are women $[4,5]$ and the highest incidence is around 18 years of age [6].Trichotillomania usually begins at the age of 11-13 years [4, 7]. Current theoretical etiopathology of TTM includes the hypotheses: 1) neuroanatomical [5], referring to the observations made by Keuthen et al. [8] on smaller cerebellar volume in TTM-patients than in control group and confirmed increased bilateral cerebellar metabolism and in the upper right parietal cortex of not treated TTM patients, 2) genetic [5] with the inheritance rate estimated at 76.2\% [9], 3) neurobiological [10] in relation to the research results of Jacobs and Fornal [11] who reported a correlation between serotonergic neuronal activation and repetitive motor activity, 4) psychological-related to the importance of traumatic events in TTM development.Gershun et al. found that $76 \%$ of TTM cases were accompanied by stressful life events, of which $16 \%$ met the criteria for diagnosis ofposttraumatic stress disorder(PTSD) [12]. A similar relationship can be found in research by Lochner, where he obtained higher scores in the Revised Childhood Trauma Questionnaire (measuring the severity of symptoms associated with abuse and neglect in the field of physical, mental and sexual abuse of children) in people with TTM [13].

Historically, the first information about TTM can be found in the literature of many epochs, starting from the Bible, through the fourth century BC, when the first scientific medical text appeared - Epidemics -by Hippocrates, the 18th century French description of trichophagy (compulsive habit of eating hair), when describing "bezoar" in the 16-year-old boy, till 20th century, when the "epidemic of hair pulling" was described in detail in English orphanages $[14,15,16]$.

The main locations of hair pulling are: 1) the head (86\%), 2) the eyelashes (52\%), 3) the eyebrows (38\%), 4) the pubic region (27\%), 5), legs (18\%) [17]. TTM usually begins at age 11-13 years [20], and the greatest severity of the disorder is in the age group 13-18 years, which corresponds to the onset of puberty and the associated stressful factors [18].

The literature distinguishes three types of TTM: type I without tension and anxiety, and followed by relief; type II referred to by researchers as an automatic when the patient pulls out hair without the involvement of attention; Type III intentionally pulling hair: conscious action connected with the presence of stronger impulses, growing tension and thoughts of pulling of hair [32].

Hair pulling is often accompanied by ritualized steps: scratching the scalp, selecting hair to pull, haircurling, shredding of hair or torn hair store, insertion of pulled hairinto the mouth, some of which is swallowed (trichophagia) $[18,19,20]$. First-line therapy for trichotillomania is based primarily on long-term psychotherapy, with only the supportive role of pharmacotherapy (mainly SSRI, SNRI, clomipramine) [18-29]. However, in many cases, the adverse drug profile can make the pharmacological options as the second choice treatment. A more effective solution for most patients is to undertake psychotherapy not only with the patient but also with the whole family [30,31].

\section{Case study}

A 16 year old student of the first class ofsecondary technical school of catering. From the age of 11 she has been treated unsystematically in Mental Health Counseling Center because of emotional lability, self-aggressive behavior, absence at school and verbal and physical aggression against her parents.

In perinatal and early childhood history, she was born from gestation II, by caesarean section at 8 months (preterm birth - 34 weeks), without perinatal complications (APGAR 9), early development was normal. In addition to suffering fromchildhood infectious diseases, she was somatically healthy. She grew up in a dysfunctional family: when the patient was 11 years old, her mother moved out of the house to another man, and by the court decision she was living with her father until her departure to boarding school.The patient's family was supervised by a guardian for domestic violence. Marital problems and lack of communication between parents had a significant negative impact on the girl's health many times. The first episodes of Trichotillomania behaviors occurred at the age of 11 - after the patient's grandfather's death, when the conflicts between the patient's parents were fully disclosed. Other self-aggressive behaviors such as burning skin with matches or leg injuries were also present in the past medical history.

In the family history of psychiatric disorders,patient'smother had beentreated due to recurrent depressive disorders.

Currently this isthe third psychiatric hospitalization, the previous two hospitalizations in 2014 in the Department of Child Psychiatry in District Hospitals with the diagnosis: mixed behavioral and emotional disorders (F92.8) and Trichotillomania (F63.3). In the medical history, the treatment had been modified many times by using a variety of therapies: Chlorprothixen (30 mg / day), Fluoxetine (20 mg / day) Risperidone (1.5 mg / day), 
Valproic acid (600 mg / day). Despite the pharmacological treatment and the psychotherapeutic treatment, no longterm remission has been achieved.

The current deterioration of mental status in the form of increased compulsive behaviors (i.e.hair pulling from different parts of the body) and depressed mood, insomnia, anhedonia, withdrawal from social contacts, difficulty in concentration and learning, was associated with intensified conflicts between parents who engaged their daughter in their problems, trying to depreciate and ridicule the other parent in her eyes.

On admission to the ward, the patient was auto- and allo-mentally oriented, in clear consciousness, tense, without psychotic symptoms, in depressed mood, responded to questions in a low voice, not keeping eye contact, confirmed constantly occurring obsessive hair pulling from the body. In apparent conflict with the mother (during conversation with the mother she was attacking, irritable).

In physical examination: a small amount of hair on the body, significant hair loss in the scalp, no eyelashes and eyebrows, healed scars on the front and lateral sides of both thighs after previous self-mutilation with sharp instruments. High risk of suicide, in MINI scale -19 points.

During the 3-month stay in the clinic, a clear relationship between the intensification of conflicts between parents and the severity of TTM symptoms was revealed. At first, she was depressed, but under the influence of therapeutic effects her condition improved. Hair pulling was also reduced. The patient repeatedly emphasized that the parents involved her in their conflict. The parents communicated via the patient, which affected the deterioration of her mental condition. The patient revealed symbiotic features - claimed that ", alone she cannot cope, parents know what is best for her".

By the parents' decision sheattended tosecondary technical school of catering, even though it was not in her interests. Periods of improvement were seen in the functioning of the patient who underwent rapid deterioration after parental quarrels, in which they engaged their daughter.

During her stay in the ward, the patient had a full package of laboratory tests made, which showed no abnormalities. The patient during hospitalization reported numerous abdominal pains - abdominal ultrasound was performed. The examination did not show any changes in the examined structures. In addition, EEG test was performed, which was within the normal range.

Psychological diagnostics was also made to assess the patient's personality and to reveal potential factors that could influence the existing disorder. In addition to free diagnostic techniques, i.e. medical history and observation, experimental and clinical trials were used to sys- tematically map the behavioral chain at times of increased need for hair pulling. The Multiphasic Personality Inventory (MMPI)and Adjective Check List Test (ACL) were used as standardized questionnaires. Additionally semistructured projection tool -Sack's and Sidney Sentence Completion Test wasused.

Free diagnostic techniques. The patient initially expressed a reluctance to contact the psychologist, but gradually became willing to talk. Her statements were consistent, logical and comprehensive. Observation of the patient indicated the attitude of anxiety, shyness and withdrawal. During the first weeks of hospitalization, she did not have any relationships to other patients or staff. She used only single words spoken in a hushed voice. Most of the time she spent in hospital bed, showing no interest in her surroundings or any other activities.

MMPI questionnaire. Control scales allowed for concluding about a reliable approach to the test situation and an adequate presentation of one's well-being and functioning. The highest scales were: Depression, Schizophrenia, Psychastenia. The results indicated: selfdissatisfaction, passivity in life situations and lack of resilience to difficult situations. In terms of well-being, the results were as follows: reduced mood, depression, loneliness, tension, anxiety, moodiness, over-sensitivity and anxiety and lack of security. In addition, according to the ICD-10 classification, the obtained profile suggests the presence of symptoms of moderate depression (F33.1).Functioning of the examined patient in the light of obtained results is characterized by: shyness, excessive analysis, difficulty expressing feelings openly, especially anger, experiencing difficulties in contact with others, lack of social skills, low assertiveness and dependence on the group. In stressful situations, the examined patient is not able to make decisions or to solve a problem and reacts with auto-aggression, meaning that she does not have the mechanisms of obtaining psychological comfort.

ACL Test. The control scales indicated a reliable self-description of the examined patient and willingness to cooperate with the investigator. The results are indicative of a small "number of adjectives used in the text," above the average "number of negative adjectives", on a scale of needs - an increased need for "support from others", "humiliation", "subordination", reduced need for "domination," heterosexual contacts "; in the thematic scales: increased tendency to "self-control", small "confidence to self", low score in "ideal self-image scales"; in transactional analysisscale: on the levelof functioning of "adopted child " and a lack of shaped role of "protecting parent", while in the originality and intelligence scales with high potential in terms of thinking.The resulting profile should be interpreted as follows: in self-image self-centeredness, low self-esteem, doubts about self- 
esteem, fear of new experiences, search for security, mood swings, impulsiveness, feelings of powerlessness in the face of crises, experiencing dilemmas and internal conflicts. In interpersonal relationships, which the subject looks at with anxiety and bad feelings, she feels uncertain, afraid to make choices, has the need for support and subordination, and the need for social approval.

Multiphasic Personality Inventory (MMPI). The patient performed the test, completing all the items in a sincere way. Of particular interest is the material on the receipt of family relationships by the subject. The mother, now the main figure of relationship, is at the same time the source of internal conflicts and the model of hypersensitivity. The father, who is a source of peace and sense of security, is not a close object of family bonds. In childhood memories, the patient spent happy time only with her grandfather. After his death and uncompleted mourning, she began to pull her hair. The patient reveals many of her fears regarding the ability to cope independently in today's life and to shape the future. She is convinced that she is weak and sensitive, she has no way to overcome difficulties. She does not specify any specific goals for the future.

The psychological examinations made during the previous hospitalization were also taken into account:

Wechsler Intelligence Scale for Children-Revised

WISC-R. The tested patient in the Full Scale scored 91 II, Verbal Scale - 96 II, Non-verbal Scale - 87 II. The overall development of cognitive abilities was at an average level. In the patient, the average level concerned: knowledge of the message, abstract thinking in verbal material, definition of concepts, perception of detail, logical causal thinking, and visual analysis and synthesis. Below average level concerned the ability to: operate on numerical material and learn on the visual material, while above the norm understanding social meanings.

Both automatic (habitual) and target TTM subtypes were diagnosed.

During the hospitalization, the therapy was mainly based on psychotherapeutic work conducted in the cognitive-behavioral domain, in the paradigm of dialectical behavioral therapy (DBT) and pharmacotherapy.

Binding links, relationships - behaviors, feelings from the body, opinions, thoughts, expectations, external events, behavior of others, emotions and feelings

\section{Problem behaviors}

Sensitivity, susceptibility - illness, irregular nutrition or sleep, drugs, alcohol, drugs, lots of stress, intense emotions,

Consequences

Harmful event

\section{When did the sequence start that led to problematic behavior}

The main goals of psychotherapeutic therapy were to reduce: life-threatening behaviors and behavior that interfered with therapy, poor co-operation in the past, suicidal thoughts, suicide plans, self-harm (skin lesions). Reducing ofbehaviors interfering with quality of life: hairpulling, depressive symptoms, problems in relations with parents. Developing behavioral skills: regulating emotions, effectiveness in interpersonal relationships, tolerance of mental discomfort, mindfulness, solving dilemmas in parent-child relationships. However, it is important to consider the important and necessary work with the invalid family system.

In addition to individual therapy, systematic weekly work with the patient's parents was conducted. First, a mediation contract was made, then parental mediation was undertaken in the interest of the child. The parents were taught basic communication skills. A multi-family therapeutic workshop was also devoted to the exercise of mindfulness and empathic contact.

The patient learned in the ward to recognize and name the emotions and identify her own "I" susceptible to injury. She perceived her impulsiveness and acquired the ability to tolerate emotional discomfort. She also developed effectiveness in interpersonal relationships, both in contact with parents and peers staying in the clinic. She learned to empower her feelings and express her needs. She was convinced of the possibility of coping with the future and feeling of control over her decisions, skills, and relationships with others. She also worked on pulling her hair, which was largely a habit. She used a self-monitoring card and gradually gained control over her long-term habits.

The analysis of the psychological tests confirmed in the patient the presence the following functional difficulties: moodvolatility, difficulty in alleviating negative emotional tension in tough for her situations - responding by helplessness, and the use of ineffective ways of coping with stress, low self-esteem, poor social functioning, which may have resulted from attitude of anxiety. It has been found that the described symptoms are associated with well-established methods of behavior characteristic for avoidant and dependent personality and trichotillomania-type disorders. In the analysis the following behavioral patterns were identified: Emotional vulnerability to harm, Self-invalidation, Inevitable crises, Suppressed mourning, Active passivity, Apparent competence.

As part of the pharmacological procedures, fluvoxamine (max.200 mg / day), aripiprazole (max.7, $5 \mathrm{mg} /$ day), was used and the improvement in mood and a slight decrease in the trichotillomania intensity wasobserved. 
Figure 1. Behavioral Chain Analysis Method by which dialectical behavioral therapy was performed in a patient.

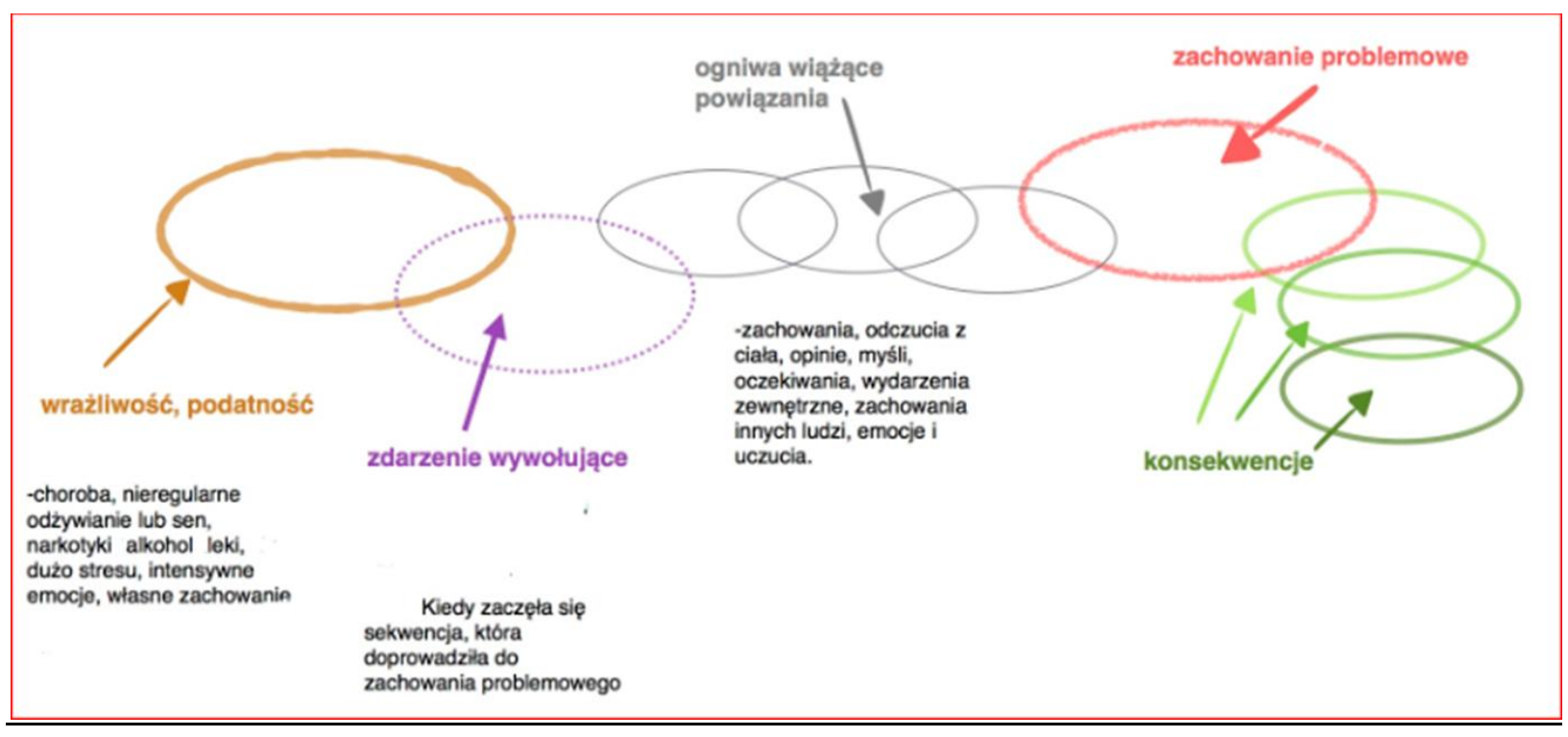

During the 3-month stay in the clinic, there was an obvious relationship between the intensification of conflicts between parents and the severity of Trichotillomaniasymptoms. Clear periods of improvement in the patient's behavior were rapidly aggravated by the parental quarrels in which the daughter was involved. At the same time, the patient's parents undertook family therapy, which contributed to the reduction of conflicts between them and, in the end, hairpulling in the patient.

The patient was discharged from the hospital with the diagnosis according to ICD -10 [1]:

Trichotillomania (F63.3), Major depressive disorder, single episode, moderate(F32.1), Inappropriate (excessive) parental pressure (Z62.6)Problems in relationship with in-laws-Inadequate family support (Z63.2).

After discharge from the Clinic, the patient regularly reported to the designated appointments in Mental Health Outpatient Clinic. She used the opportunity to take psychotherapy in outpatient settings. The girl reported that for the first month after leaving the hospital, she did not pull out her hair, and as time passed, her tendency to unintentional pulling hair was reversed, but it was mild and affected the individual hair, making her head gradually regain its former appearance.

\section{Discussion}

The case of a patient with compulsive hair-pulling disorder draws attention to the importance of an abnormal family system and ineffective ways of coping with stress in the development and maintenance of TTM symptoms. The onset of the disease at the age of 11 coincided with the loss of the object of love-grandfather's death and family conflicts, and coincided with the addressed in the literature onset of TTM from 11 to 13 years [4, 7].In the girl,there were characteristic symptoms of TTM, i.e. pulling hair from the skin of the body focusing on the hair on the scalp, eyelashes, eyebrows, as a result of inefficient ways of coping with stress, impaired social functioning, withdrawal from interpersonal contacts while meeting the diagnosis criteria contained in the ICD-10 [1] and DSM 5 [2]. Both automatic and habitual TTM subtypes were diagnosed [32]. The psychotherapeutic interventions (DBT -Dialectic Behavioral Therapy) covered both the patient (individual psychotherapy) and the whole family (family psychotherapy, family mediation, workshops for parents).Despite the parents' rigid attitudes and the dysfunctional family system, with a particular kind of "balance" in relationships between parents, with the key role of the patient in communicating each information, it was possible to make changes that allowed direct communication between members of the system, alleviation of conflicts, and consequent discharge of the patient in good mental condition. Pharmacological treatment included the use of fluvoxamine and aripiprazole.

Conclusions:

1. In the described case, traumatic events and pathological relations of the closest family members became the triggering factors, and also supporting the Trichotillomania symptoms .

2. According to the guidelines of the Trichotillomania Learning Center-Scientific Advisory Board (2008) [30], the use of comprehensive treatment covering both the patient - individual psychotherapy (mainly cognitive-behavioral psychotherapy) including pharmacotherapy and its family system (family psychotherapy, family mediation, workshops for parents) has brought positive therapeutic effects. 


\section{WSTĘP}

Trichotillomania (TTM) jest zaburzeniem charakteryzującym jest powtarzalnym i kompulsywnym wyrywaniem włosów, zaklasyfikowanym w ICD-10 do kategorii zaburzeń nawyków i popędów ( F63.3) [1], zaś w DSM-5 zaliczanym do grupy zaburzeń obsesyjno-kompulsyjnych pod nową nazwą: hair pulling disorder [2]. Rozpowszechnienie TTM szacuje się na $0,6-3,4 \%$ populacji [3], z czego prawie $90 \%$ stanowią kobiety $[4,5]$, a największy okres zachorowalności przypada na okres około 18 lat [6]. Trichotillomania rozpoczyna się zazwyczaj w wieku 11-13 lat [4, 7]. Do aktualnych teorii etiopatologicznych dotyczących TTM zalicza się hipotezy: I) neuroanatomiczną [5], w związku z obserwacjami poczynionymi przez Keuthen i wsp. [8] dotyczącymi mniejszej objętości móżdżku u cierpiących na TTM w porównaniu z kontrolą oraz stwierdzonym zwiększonym metabolizmem w móżdżku obustronnie oraz w górnej korze ciemieniowej po stronie prawej u nieprzyjmujących leków chorych na TTM oraz), II) genetyczną [5] z odziedziczalnością szacowaną na 76,2\%. [9], III) neurobiologiczną [10] w nawiązaniu do wyników badań Jacobsa i Fornala [11], którzy odnotowali korelację między pobudzeniem neuronów serotoninergicznych i powtarzalnymi czynnościami ruchowymi, IV) psychologiczną -dotyczącą znaczenia traumatycznych wydarzeń życiowych w rozwoju TTM. Z badań Gershuny i wsp. wynika, że w 76\% przypadków TTM towarzyszyły stresujące wydarzenia z życia, z czego aż $16 \%$ spełniało kryteria rozpoznania PTSD [12]. Podobną zależność możemy znaleźć w badaniach Lochnera, gdzie uzyskano wyższe wyniki w kwestionariuszu Revised Childhood Trauma Questionnaire (mierzącym stopień nasilenia objawów związanych z nadużyciami i zaniedbaniami na polu fizycznym, psychicznym oraz seksualnym u dzieci) u osób cierpiących na TTM [13].

Historycznie pierwsze informacje dotyczące TTM można znaleźć w literaturze wielu epok począwszy od opisów zawartych w Biblii, przez wiek IV wiek p.n.e, gdy pojawił się pierwszy naukowy tekst medyczny- Epidemika - dzieło Hipokratesa, XVIII wieczny francuski opis trichofagii (kompulsywnego nawyku zjadania włosów) przy okazji opisu „, bezoaru” u 16 latka, po wiek XX gdzie w dokładny sposób opisano "epidemię wyrywania włosów" w angielskich sierocińcach [14,15,16].

Głównymi miejscami wyrywania włosów są :1) głowa $(86 \%), 2)$ rzęsy $(52 \%), 3)$ brwi $(38 \%), 4)$ region łonowy $(27 \%), 5)$ nogi $(18 \%)$ [17]. TTM rozpoczyna się zazwyczaj w wieku 11-13 lat [20], a największe nasilenie zaburzenia uwidacznia się w przedziale wiekowym 1318 lat, co odpowiada początkowi okresu pokwitania i związanymi z nim czynnikami stresującymi [18].

W literaturze wyrózniono trzy typy TTM: typ I) bez napięcia i lęku oraz następowej ulgi, typ II) określany przez badaczy jako automatyczny, gdy pacjent wyrywa owłosienie bez zaangażowania uwagi, typ III) celowe wyrywanie włosów: czynność świadoma, związana z obecnością silniejszych impulsów, narastającym napięciem i myślami o wyrywaniu sobie włosów [32].

Wyrywaniu włosów często towarzyszą zrytualizowane czynności: drapanie owłosionej skóry, wybieranie włosów do wyrwania, zwijanie włosów, rozdrabnianie włosów czy ich przechowywanie wkładanie wyrwanych włosów do ust, z czego część je połyka (trichofagia) [18, $19,20]$. Terapia pierwszego rzutu w leczeniu trichotillomanii opiera się głównie na długotrwałej psychoterapii, przy jedynie wspierającej roli farmakoterapii (głównie leki przeciwdepresyjne z grupy SSRI, SNRI, klomipramina) [18 - 29]. Jednak u wielu chorych profil działań niepożądanych może czynić opcje farmakologiczne metodami leczenia II wyboru. Skuteczniejszym rozwiązaniem dla większości pacjentów jest podjęcie psychoterapii nie tylko samego chorego, ale przede wszystkim objęciem terapią całego systemu rodzinnego [30,31].

\section{OPIS PRZYPADKU}

Pacjentka lat 16, uczennica I klasy technikum gastronomicznego. Od 11 roku życia leczona niesystematycznie w Poradni Zdrowia Psychicznego z powodu labilności emocjonalnej, zachowań autoagresywnych, niewywiązywania się z obowiązku szkolnego oraz agresji słownej i fizycznej wobec rodziców.

Z wywiadu okołoporodowego i wczesnodziecięcego wynika, że urodziła się z ciąży II, poprzez cięcie cesarskie w 8 miesiącu ciąży (poród przedwczesny- 34 tydzień), bez powikłań okołoporodowych (APGAR 9), rozwój wczesnodziecięcy przebiegał prawidłowo. Poza przebyciem chorób zakaźnych wieku dziecięcego- somatycznie zdrowa. Wychowywała się w rodzinie dysfunkcyjnej: gdy pacjentka miała 11 lat, matka wyprowadziła się z domu do innego mężczyzny, a pacjentka na mocy decyzji sądu rodzinnego zamieszkiwała z ojcem aż do momentu wyjazdu do szkoły z internatem. Rodzina pacjentki została objęta dozorem kuratora z powodu przemocy w rodzinie. Problemy małżeńskie oraz brak komunikacji między rodzicami w znacznym, negatywnym stopniu wielokrotnie odbijały się na stanie zdrowia dziewczyny. Pierwsze epizody zachowań noszących znamiona Trichotillomanii pojawiły się w wieku lat 11 - po śmierci dziadka pacjentki, kiedy to ujawniły się w pełni konflikty małżeńskie pomiędzy rodzicami pacjentki. W wywiadzie obecne były także inne zachowania autoagresywne, takie jak przypalania się zapałkami czy okaleczanie nóg ostrymi przyrządami.

W wywiadzie rodzinnym dotyczącym występowania zaburzeń psychicznych $\mathrm{w}$ rodzinie matka pacjentki-leczyła się z powodu zaburzeń depresyjnych nawracających. 
Aktualnie trzecia hospitalizacja psychiatryczna , poprzednie dwie hospitalizacje w 2014 roku w Oddziałach Psychiatrii Dziecięcej w Szpitalach Rejonowych z rozpoznaniem: Mieszane zaburzenia zachowania i emocji F92.8 oraz Trichotillomania F63.3. W wywiadzie wielokrotne modyfikowano leczenie stosując różnorodne terapie: Chlorprothixen (30mg/dobę), Fluoksetyna (20 mg/dobę), Risperidon (1,5 mg /dobę), Kwas walproinowy (600 mg /dobę). Pomimo leczenia farmakologicznego oraz podjętych działań psychoterapeutycznych nie uzyskiwano długotrwałych remisji.

Aktualne pogorszenie stanu psychicznego pod postacią nasilenia się czynności kompulsywnych (tj. wyrywania owłosienia z różnych okolic ciała) oraz obniżonego nastroju, bezsenności, anhedonii, wycofania się z kontaktów społecznych, trudności w koncentracji, w nauce, wiązało się z nasileniem konfliktów miedzy rodzicami, którzy angażowali córkę w swe problemy, starając się zdeprecjonować w jej oczach drugiego rodzica i ośmieszyć.

Przy przyjęciu do oddziału pacjentka była zorientowana auto i allopsychicznie $w$ jasnej świadomości, napięta, bez objawów psychotycznych, w obniżonym nastroju, na pytania odpowiadała ściszonym głosem, nie utrzymując kontaktu wzrokowego, potwierdzała stale występujące natrętne wyrywanie włosów z ciała. W widocznym konflikcie z matką (w rozmowie z matką atakująca, drażliwa). W badaniu fizykalnym: widoczna niewielka ilość owłosienia na ciele, znaczne ubytki owłosienia skóry głowy, brak rzęs oraz brwi, wygojone blizny na przedniej oraz bocznej stronie obu ud po wcześniejszych samookaleczeniach ostrymi narzędziami. Wysokie ryzyko samobójcze, w skali MINI -19 punktów.

W trakcie 3 miesięcznego pobytu w Klinice ujawnił się ewidentny związek pomiędzy nasileniem się konfliktów między rodzicami, a nasileniem objawów TTM. Początkowo utrzymywał się obniżony nastrój, jednak pod wpływem oddziaływań terapeutycznych uległ poprawie. Osłabieniu uległo także wyrywanie włosów. Pacjentka niejednokrotnie podkreślała, że rodzice włączają ją w konflikt między sobą. Rodzice komunikowali się przez pacjentkę, co wpływało na pogorszenie jej samopoczucia. Pacjentka ujawniała cechy symbiotyczne - twierdziła, iż „sama nie da sobie rady, rodzicie wiedzą, co jest dla niej najlepsze". Decyzją rodziców rozpoczęła naukę w technikum gastronomicznym, pomimo, iż nie było to $\mathrm{w}$ zakresie jej zainteresowań. Widoczne były okresy poprawy w funkcjonowaniu pacjentki, które ulegały gwałtownym pogorszeniom po kłótniach rodziców, w które angażowali córkę.

Podczas pobytu w Oddziale pacjentka miała wykonany pełen pakiet badań laboratoryjnych, który nie wykazał odchyleń od normy. Pacjentka w trakcie hospitalizacji zgłaszała liczne dolegliwości okolic brzucha - wykonano USG jamy brzusznej. Badanie nie wykazało zmian w obrębie badanych struktur. Dodatkowo wykonano badanie EEG, którego zapis pozostawał w granicach normy.

Przeprowadzono także diagnostykę psychologiczną mającą na celu ocenę osobowości pacjentki oraz ujawnienie potencjalnych czynników mogących wpływać na istniejące zaburzenie. Oprócz swobodnych technik diagnostycznych, tj. wywiadu i obserwacji, zastosowano próby eksperymentalno-kliniczne, polegające na systematycznym odwzorowywaniu łańcucha behawioralnego w momentach nasilenia potrzeby wyrywania włosów. Ze standaryzowanych kwestionariuszy do badania wykorzystano test WISKAD-MMPI $\boldsymbol{i}$ Test Przymiotnikowy ACL Dodatkowo użyto pół-ustrukturyzowanego narzędzia projekcyjnego - Testu Uzupełniania Zdań oraz testu WISC-R.

Swobodne techniki diagnostyczne. Pacjentka początkowo wyrażała niechęć do kontaktu z psychologiem, jednak stopniowo nabierała chęci do rozmów. Wypowiedzi były spójne, logiczne i wyczerpujące. Obserwacja pacjentki wskazywała na postawę lękową, nieśmiałość i wycofanie. Podczas pierwszych tygodni hospitalizacji nie nawiązywała relacji ani z innymi pacjentami, ani z personelem. Używała jedynie pojedynczych słów wypowiadanych ściszonym głosem. Większość czasu spędzała w łóżku szpitalnym, nie wykazując zainteresowania otoczeniem ani jakimikolwiek zajęciami własnymi.

Kwestionariusz WISKAD-MMPI [ 33] .Skale kontrolne pozwalały wnioskować o rzetelnym podejściu do sytuacji badania i adekwatnej prezentacji własnego samopoczucia i funkcjonowania. Najwyższymi skalami okazała się być: Depresja, Schizofrenia, Psychastenia. Otrzymane wyniki wskazywały przede wszystkim na: niezadowolenie z siebie, bierność w sytuacjach życiowych i nieodporność na sytuacje trudne. $\mathrm{W}$ aspekcie samopoczucia wyniki oznaczały: obniżony nastrój, przygnębienie, uczucie osamotnienia, napięcie, niepokój, nastrojowość, nadmierną wrażliwość oraz obezwładniający lęk i brak poczucia bezpieczeństwa. Dodatkowo, zgodnie z klasyfikacją ICD-10 uzyskany profil sugeruje występowanie objawów depresji w stopniu umiarkowanym (F33.1). Funkcjonowanie badanej $\mathrm{w}$ świetle uzyskanych wyników cechuje: nieśmiałość, nadmierne analizowanie, trudność wyrażania w sposób otwarty uczuć, zwłaszcza złości, doświadczanie trudności w kontaktach z innymi, brak umiejętności społecznych, niska asertywność i zależność od grupy. W sytuacjach stresujących badana nie czuje się zdolna do podejmowania decyzji ani do rozwiązania problemu i reaguje autoagresją, co oznacza, iż nie posiada mechanizmów służących uzyskaniu komfortu psychicznego.

Test Przymiotnikowy ACL [34]. Skale kontrolne wskazywały na wiarygodny samoopis badanej oraz chęć 
współpracy z badającym w sytuacji badania. Uzyskane wyniki świadczą o: małej „liczbie przymiotników użytych w tekście”, ponadprzeciętnej „liczbie negatywnych przymiotników", w skalach potrzeb - o nasilonej potrzebie „Wsparcia ze strony innych", „Upokorzenia” „,Podporządkowania” ,obniżonej potrzebie „Dominacji”, „Kontaktów heteroseksualnych” ; w skalach tematycznych: o zwiększonej skłonności do „Samokontroli” , małym „Zaufaniu do siebie”, niskim wyniku w „Skali idealnego obrazu siebie"; w skalach analizy transakcyjnej: o funkcjonowaniu z poziomu „Adoptowanego Dziecka” i braku ukształtowanej roli „Opiekuńczego Rodzica”, natomiast w skalach oryginalności i inteligencji o wysokim potencjale w zakresie myślenia. Uzyskany profil należy interpretować następująco: w obrazie siebie - koncentracja na sobie, małe zaufanie do siebie i wątpliwości co do własnych możliwości, obawa przed nowymi doświadczeniami, poszukiwanie bezpieczeństwa, zmienność nastrojów, impulsywność, poczucie bezsilności w obliczu kryzysów, doświadczanie rozterek i konfliktów wewnętrznych. W relacjach interpersonalnych, na które badana patrzy z niepokojem i złymi przeczuciami, czuje się niepewnie, obawia się dokonywania wyborów, ma potrzebę wsparcia i podporządkowania oraz dużą potrzebę społecznej aprobaty.

Test Uzupełniania Zdań [35] Badana wykonała test, uzupełniając wszystkie itemy w szczery sposób. Szczególnie interesujący jest materiał w zakresie odbioru przez badaną relacji rodzinnych. Matka, będąca obecnie główną figurą przywiązania, stanowi jednocześnie źródło konfliktów wewnętrznych i modeluje nadwrażliwość. Ojciec, pozostający źródłem spokoju i poczucia bezpie- czeństwa, nie jest bliskim obiektem więzi. We wspomnieniach $\mathrm{z}$ dzieciństwa szczęśliwy czas badana spędzała jedynie z dziadkiem, po którego śmierci i nieprzeżytej do końca żałobie rozpoczęło się wyrywanie włosów. Badana ujawnia swoje liczne lęki dotyczące możliwości samodzielnego poradzenia sobie w obecnym życiu oraz kształtowaniu przyszłości. Żywi przekonanie, że jest słaba i wrażliwa, nie posiada sposobu na pokonywanie trudności. Nie precyzuje żadnych konkretnych celów na przyszłość.

Przy ocenie wzięto pod uwagę również badania psychologiczne wykonane w czasie poprzednich hospitalizacji:

WISC-R [36] Badana w Skali pełnej uzyskała 91 II, Skala słowna- 96 II, Skala bezsłowna- 87 II. Ogólny rozwój zdolności poznawczych kształtował się na poziomie przeciętnym. U pacjentki na poziomie przeciętnym znajdowały się: znajomość wiadomości, myślenie abstrakcyjne na materiale słownym, definiowanie pojęć, spostrzegania szczegółów, myślenie logiczne przyczynowe oraz analiza i synteza wzrokowa. Poniżej przeciętnej ukształtowana była zdolność do: operacji na materiale liczbowym i uczenia się na materiale wzrokowym, zaś powyżej normy rozumienie znaczeń społecznych.

Zdiagnozowano zarówno automatyczny (nawykowy), jak i celowy podtyp TTM.

Podczas pobytu w oddziale terapia pacjentki w głównej mierze polegała na pracy psychoterapeutycznej prowadzona w nurcie poznawczo-behawioralnym, w paradygmacie dialektycznej terapii behawioralnej (DBT) oraz farmakoterapii.

Ryc. 1 Metoda Analizy Łańcucha Behawioralnego wg którego przeprowadzana była dialektyczna terapia behawioralna u pacjentki.

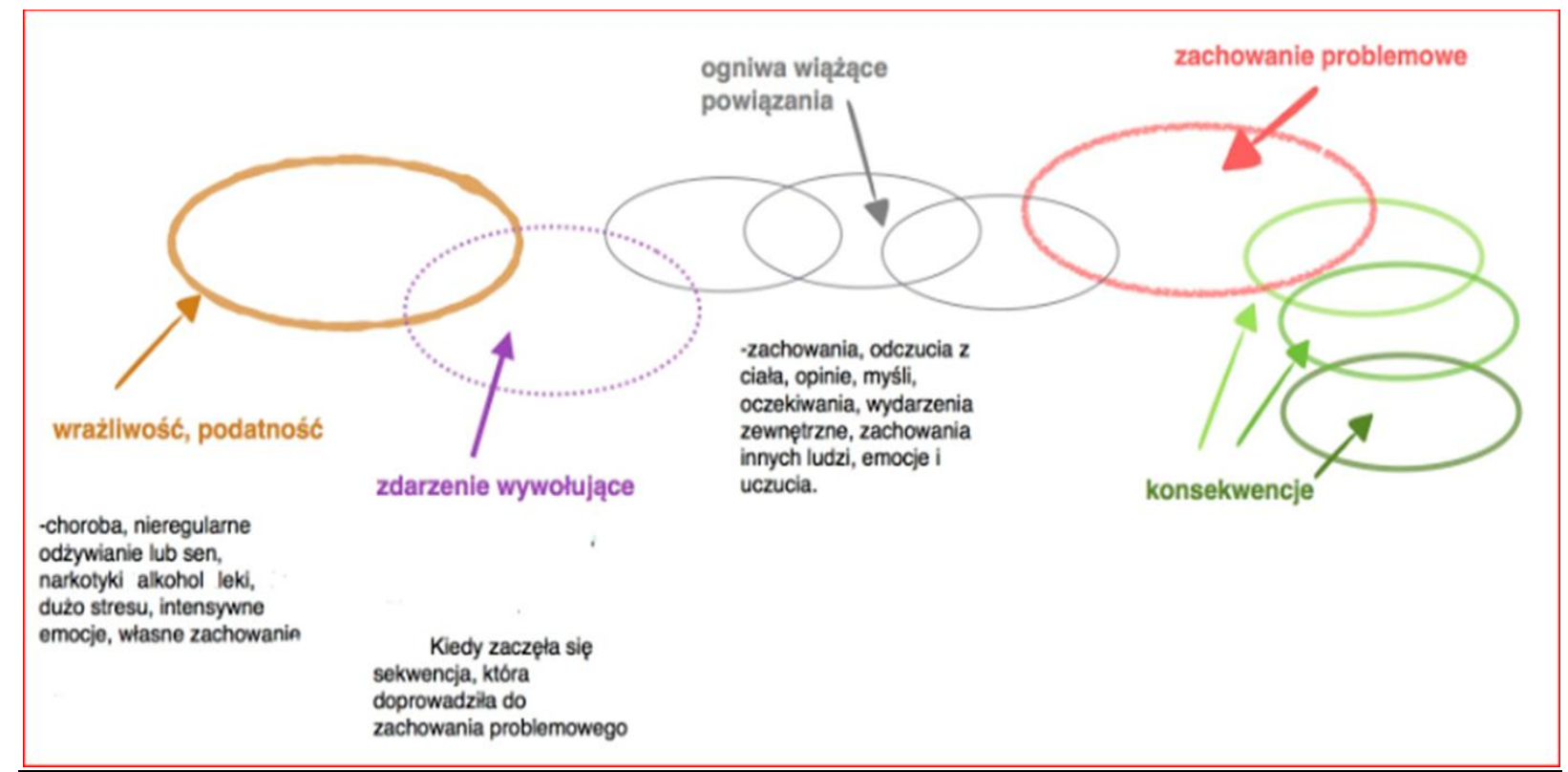


Głównymi celami terapii psychoterapeutycznej była redukcja: zachowań zagrażających życiu oraz zachowań kolidujących z terapią, słabej współpracy w leczeniu w przeszłości, myśli samobójczych, planów samobójczych, samouszkodzeń (okaleczeń skóry). Redukowanie zachowań kolidujących z jakością życia: wyrywania włosów, objawów depresyjnych, problemów w relacjach z rodzicami. Rozwijanie umiejętności behawioralnych: regulowania emocji, skuteczności w relacjach interpersonalnych, tolerowania dyskomfortu psychicznego, uważności, rozwiązywania dylematów w relacjach rodzic-nastolatek. Jednak należy uwzlędnić jeszcze jakże ważną i potrzebną pracę z unieważniającym systemem rodzinnym.

Oprócz terapii indywidualnej prowadzono systematyczną, cotygodniową pracę z rodzicami pacjentki. Najpierw zawarto kontrakt mediacyjny, następnie podjęto mediacje małżeńskie w ramach troski o dobro dziecka. Kolejno uczono rodziców podstawowych umiejętności komunikacyjnych. Rozpoczęto również wielorodzinny warsztat terapeutyczny poświęcony ćwiczeniu uważności i empatycznemu kontaktowi.

Pacjentka w ramach terapii na Oddziale nauczyła się rozpoznawać i nazywać emocje oraz rozpoznawać własne „ja” podatne na zranienie. Dostrzegła swoją impulsywność i nabywała umiejętności tolerowania dyskomfortu emocjonalnego. Rozwijała również skuteczność w relacjach interpersonalnych, zarówno w kontakcie z rodzicami, jak i rówieśnikami przebywającymi w Klinice. Uczyła się uprawomocniać swoje uczucia i wyrażać potrzeby. Nabierała przekonania o możliwości poradzenia sobie z przyszłością i poczucia sprawczości odnośnie własnych decyzji, umiejętności i relacji z innymi .Jednocześnie pracowała nad wyrywaniem włosów, będącym w dużej mierze zachowaniem nawykowym. Stosowała kartę samoobserwacji i stopniowo nabierała kontroli nad opanowaniem wieloletniego nawyku.

Analiza przeprowadzonych badań psychologicznych potwierdziła występowanie $\mathrm{u}$ pacjentki następujących trudności w funkcjonowaniu: zmienności nastroju, trudności w rozładowaniu negatywnego napięcia emocjonalnego, w sytuacjach dla niej trudnych - reagowania bezradnością, oraz stosowaniem nieefektywnych sposobów radzenia sobie ze stresem, niskiego poczucia własnej wartości, osłabienia funkcjonowania społecznego, które mogły wynikać z postawy lękowej. Stwierdzono, że opisane objawy mają związek z utrwalonymi sposobami zachowania o cechach osobowości unikającej i zależnej oraz zaburzeniami w zakresie nawyków w postaci trichotillomanii.W analizie rozpoznano wzorce behawioralne: Emocjonalnej podatności na zranienie, Samounieważnienia, Nieuniknionych kryzysów, Powstrzymywanej żałoby, Aktywnej bierności, Pozornej kompetencji.
W ramach oddziaływań farmakologicznych u pacjentki zastosowano fluwoksaminę (max.200 mg/dzień), arypiprazol (max.7, 5 mg / dzień), obserwując poprawę w zakresie nastroju i niewielkiego zmniejszenia nasilenia wyrywania włosów.W trakcie 3 miesięcznego pobytu w Klinice ujawnił się ewidentny związek pomiędzy nasileniem się konfliktów między rodzicami a nasileniem objawów Trichotillomanii. Widoczne okresy poprawy w funkcjonowaniu pacjentki ulegały gwałtownym pogorszeniom po kłótniach rodziców, w które angażowali córkę. Jednocześnie rodzice pacjentki podjęli terapię rodzinną, co przyczyniło się do zmniejszenia konfliktów między nimi i w końcowym efekcie ustąpienie wyrywania włosów u pacjentki.

Pacjentka została wypisana z Oddziału z rozpoznaniem wg ICD -10 [1]: Trichotillomania F63.3, Epizod depresyjny umiarkowany F32.1, Nieodpowiedni nacisk rodzicielski i inne nienormalne cechy wychowania Z62.6 Nieadekwatne poparcie rodziny Z63.2

Po wypisie z Kliniki Pacjentka regularnie zgłaszała się na wyznaczone terminy wizyt w Poradni Zdrowia Psychicznego. Skorzystała z możliwości podjęcia psychoterapii $\mathrm{w}$ warunkach ambulatoryjnych. Dziewczyna informowała, że przez pierwszy miesiąc po opuszczeniu szpitala włosów nie wyrywała, wraz z upływem czasu powróciła skłonność do bezwiednego usuwania włosów, jednak miało ono niewielkie nasilenie i dotyczyło pojedynczych włosów, co sprawiło, że głowa pacjentki stopniowo odzyskała dawny wygląd.

\section{Dyskusja}

Przedstawiony w pracy przypadek pacjentki z zaburzeniem kompulsywnego wyrywania włosów, zwraca uwagę na znaczenie nieprawidłowego systemu rodzinnego oraz nieefektywnych sposobów radzenia sobie ze stresem w rozwoju i podtrzymaniu objawow TTM. Początek zachorowania w wieku 11 lat, zbiegł się w opisywanym przypadku z utratą obiektu miłości- śmiercią dziadka i konfliktami rodzinnymi oraz pokrywał się z podnoszonym w literaturze początkiem TTM od 11 do 13 lat [4, 7]. U dziewczynki wystąpiły charakterystyczne objawy TTM tj. wyrywanie owłosienia ze skóry ciała skupiając się na owłosieniu skóry głowy rzęs, brwi, będące wynikiem nieefektywnych sposobów radzenia sobie ze stresem, osłabienia funkcjonowania społecznego, wycofania się z kontaktów międzyludzkich spełniając przy tym kryteria rozpoznania zawarte w ICD 10 [1] oraz DSM 5 [2]. Zdiagnozowano zarówno automatyczny (nawykowy), jak i celowy podtyp TTM [32]. Oddziaływania psychoterapeutyczne (metodą Dialektycznej Terapii Behawioralnej DBT) objęły zarówno samą pacjentkę (psychoterapia indywidualna), jak i cały system rodzinny (psychoterapia rodzinna, mediacja rodzinna, warsztaty dla rodziców). Pomimo 
sztywności postaw rodziców oraz dysfunkcjonalnego systemu rodzinnego, $\mathrm{z}$ wytworzoną swoistego rodzaju „równowagą” w relacjach pomiędzy rodzicami, z kluczowa rolą pacjentki w przekazywaniu każdej informacji, udało się dokonać zmian, które umożliwiły komunikację bezpośrednią pomiędzy członkami systemu, złagodzenie konfliktów, a w konsekwencji wypis pacjentki do domu w dobrym stanie psychicznym. Farmakologicznym wsparciem terapii było włączenie do leczenia fluwoksaminy oraz arypiprazolu.

\section{Wnioski:}

1.W opisanym przypadku traumatyczne wydarzenia życiowe oraz patologiczne relacje najbliższych członków rodziny stały się czynnikiem wyzwalającym, ale i podtrzymującym objawy Trichotillomanii.

2. Zgodnie z wytycznymi Trichotillomania Learning Center-Scientific Advisory Board (2008) [30] zastosowanie kompleksowego leczenia obejmującego swym zakresem zarówno pacjentkę - psychoterapia indywidualna (głównie kognitywno-behawioralna) łącznie $\mathrm{z}$ farmakoterapią, jak i jej system rodzinny (psychoterapia rodzinna, mediacja rodzinna, warsztaty dla rodziców) przyniosło pozytywne efekty terapeutyczne.

\section{Conflict of interest}

The authors have declared no conflict of interest.

\section{References}

1. World Health Organization. The ICD-10 Classification of Mental and Behavioural Disorders. Geneva: World Health Organization; 1992.

2. Diagnostic and statistical manual of mental disorders. Fifth edition (DSM-5). Washington, DC: American Psychiatric Association; 2013.

3. Christenson GA, Pyle RL, Mitchell JE. Estimated lifetime prevalence of trichotillomania in college-students. Journal of Clinical Psychiatry. 1991; 52: 415-417.

4. Cohen LJ, Stein DJ, Simeon D, Spadaccini E, Rosen J, Aronowitz B, Hollander E. Clinical profile, comorbidity, and treatment history in 123 hair pullers - a survey study. Journal of Clinical Psychiatry. 1995; 56: 319-326

5. Woods DW, Flessner CA, Franklin ME, Keuthen NJ, Goodwin RD, Stein DJ, Walther MR, Trichotillomania Learning Ctr S. The trich otillomania impact project (tip): Exploring phenomenology, functional impairment, and treatment utilization. Journal of Clinical Psychiatry. 2006; 67: 1877-1888.

6. Mehregan AH. Trichotillomania - a clinicopathologic study. Archives of Dermatology. 1970; 102: 129-133.

7. Keren M, Ron-Miara A, Feldman R, Tyano S. Some reflections on infancy-onset trichotillomania. Psychoanal. Study Child 2006; 61: 254-272

8. Keuthen NJ, Makris N, Schlerf JE, Martis B, Savage CR, McMullin K, Seidman LJ, Schmahmann JD, Kennedy DN, Hodge SM, Rauch SL. Evidence for Reduced Cerebellar Volumes in Trichotillomania. Biol Psychiatry 2007;61:374 -381
9. Novak CE, Keuthen NJ, Stewart SE, Pauls DL. 2009. A Twin Concordance Study of Trichotillomania. Am J Med Genet Part B 150B:944-949

10. Zuchner S, Cuccaro ML, Tran-Viet KN et al. SLITRK1 mutations in trichotillomania. Mol Psychiatry 2006;11:887-9.

11. Jacobs, B. L., \& Fornal, C. A. (1995). Activation of 5-HT neuronal activity during motor behavior. Seminars in Neuroscience, 7 , 401-408

12. Gershuny, B. S., Keuthen, N. J., Gentes, E. L., Infield, A. L., \& Jenike, M. A. (2006). Current posttraumatic stress disorder and history of trauma in trichotillomania. Journal of Clinical Psychology, 62, 1521-1529

13. Lochner, C., du Toit, P. L., Zungu-Dirwayi, N., Marais, A., van Kradenburg, J., Curr, B., et al. (2002). Childhood trauma in obsessive-compulsive disorder, trichotillomania, and controls. Depression and Anxiety, 15, 66-68.

14. Evans B. A case of trichotillomania in a child treated in a home token program. J Behav Ther Exp Psychiatry 1976; 7: 197-8

15. 15. Gray JJ. Positive reinforcement and punishment in the treatment of childhood trichotillomania. J Behav Ther Exp Psychiatry 1979; 10: 125-9

16. Stabler B, Warren AB. Behavioral contracting in treating trichotillomania: case note. Psychol Rep 1974; 34: 401-2

17. Christenson GA, Mackenzie TB, Mitchell JE. Characteristics of 60 adult chronic hair pullers. Am. J. Psychiatry 1991; 148: 365-370.

18. Stein DJ, Bouwer C, Maud CM. Use of the selective serotonin reuptake inhibitor citalopram in treatment of trichotillomania. European Archives of Psychiatry and Clinical Neuroscience. 1997; 247: 234-236.

19. Iancu I, Weizman A, Kindler S, Sasson Y, Zohar J. Serotonergic drugs in trichotillomania: Treatment results in 12 patients. Journal of Nervous and Mental Disease. 1996; 184: 641-644.

20. Ninan PT, Knight B, Kirk L, Rothbaum BO, Kelsey J, Nemeroff CB. A controlled trial of venlafaxine in trichotillomania: Interim phase i results. Psychopharmacology Bulletin. 1998; 34: 221-224.

21. Marsteller FA, Knight BT, Eccard MB. A placebo-controlled trial of cognitive-behavioral therapy and clomipramine in trichotillomania. Journal of Clinical Psychiatry. 2000; 61: 47-50.

22. Grant JE, Odlaug BL, Chamberlain SR, Kim SW. Dronabinol, a cannabinoid agonist, reduces hair pulling in trichotillomania: A pilot study. Psychopharmacology. 2011; 218: 493-502

23. Odlaug BL. Clinical characteristics of trichotillomania with trichophagia.Compr. Psychiatry 2008; 49: 579-584

24. Bouwer C, Stein DJ. Trichobezoars in trichotillomania: case report and literature overview. Psychosom. Med. 1998; 60: 658-660

25. 25.Adewuya EC, Zinser W, Thomas C. Trichotillomania: A case of response to valproic acid. Journal of Child and Adolescent Psychopharmacology. 2008; 18: 533-536.

26. Berk M, McKenzie H, Dodd S. Trichotillomania: Response to lithium in a person with comorbid bipolar disorder. Human Psy chopharmacology-Clinical and Experimental. 2003; 18: 576-577.

27. Christenson, G. A., Crow, S. J., MacKenzie, T.B., et al. (May, 1994). A placebo controlled double-blind study of naltrexone for trichotillomania [Abstract]. New Research Program and Abstracts of the 150th Annual Meeting of the American Psychiatric Association.

28. Van Ameringen M, Mancini C, Patterson B, Bennett M, Oakman J. A randomized, double-blind, placebo-controlled trial of olanzapine in the treatment of trichotillomania. J Clin Psychiatry. 2010; 71:1336-1343.

29. Bloch MH, Panza KE, Grant JE, Pittenger Ch, Leckman JF. NAcetylcysteine in the Treatment of Pediatric Trichotillomania: A Randomized, Double-Blind, Placebo-Controlled Add-On Trial. 
Journal of the American Academy of Child \& Adolescent Psychiatry 2013; 52 (3): 231-240

30. Flessner ChA, Penzel F, Keuthen NJ, Trichotillomania Learning Center-Scientific Advisory Board. Current Treatment Practices for Children and Adults With Trichotillomania: Consensus Among Experts. Cognitive and Behavioral Practice 2010;17: 290-300

31. Colomb R, Franklin M, Grant JE, Keuthen NJ, Mansueto CS, Mouton-Odum S. iwsp. Expert consensus treatment guidelines for trichotillomania, skin picking and other body-focused repetitive behaviors.2011;

http://www.trich.org/dnld/ExpertGuidelines_000.pdf [dostęp: 06.12.2015]

32. Keuthen N.J., Stein D.J., Christenson G.A.: Help for hair-pullers. Oakland, Harbinger Publications, 2001

33. Płużek Z., Wartość testu WISKAD-MMPI dla diagnozy różnicowej w zakresie nozologii psychiatrycznej. Katolicki Uniwersytet Lubelski, Lublin, 1976.

34. Martowska K.: Lista Przymiotnikowa ACL. Polska adaptacja: Zespół Pracowni Testów Psychologicznych PTP, Warszawa, 2012.

35. Sacks J., Levy S.: The Sentence Completion Test. Projective Psychology: Clinical Approaches to the Total Personality. Edited by Abt L. E., Bellak. L. New York: Alfred A. Knopf, Inc., 1950. Polskie tłumaczenie: M. Choynowski, 1961.
36. Matczak A, Piotrowska A, Ciarkowska W.: WISC-R. Skala Inteligencji Wechslera dla Dzieci. Wersja Zmodyfikowana. Wydanie trzecie poprawione. Zespół Pracowni Testów Psychologicznych PTP, Warszawa, 2008.

\section{Correspondence address}

Aleksandra Siek

I Klinika Psychiatrii, Psychoterapii i Wczesnej Interwencji ul. Głuska 1, 20-439 Lublin

e-mail: ciuryloaleksandra89@gmail.com

Otrzymano: 07.11.2016

Zrecenzowano: 15.12.2016

Przyjęto do druku: 05.12.2017 